\title{
Is the risk of multiple sclerosis related to the 'biography' of the immune system?
}

\author{
Bernd Krone $\cdot$ Frank Oeffner $\cdot$ John M. Grange
}

Received: 6 January 2009/ Accepted: 9 February 2009/Published online: 1 March 2009

(c) The Author(s) 2009. This article is published with open access at Springerlink.com

\begin{abstract}
Multiple sclerosis (MS) with onset in childhood offers a unique opportunity to study the infectious background of this disease but the immune reactions against infectious agents in such children have only recently been investigated. These and other epidemiological studies strongly implicate involvement of one or more infectious agents in the aetiology of MS, with Epstein-Barr virus (EBV) being the prime candidate. Rather than being the actual cause of MS, it is more probable that these agents are involved in the development of immunoregulatory pathways. These pathways, if disturbed by hygiene-related factors including an altered sequence of infections, may generate and maintain a deficit within the immunological network that facilitates, to particular early events in the development of MS, preceding the onset of MS disease by years or a decade. A framework that can serve as a guide for further epidemiological, immunologic and molecular biologic investigations is formulated. This approach may shed light on the complex natural history of MS and may
\end{abstract}

B. Krone

Institute of Virology, University of Göttingen, Kreuzbergring 57, 37075 Göttingen, Germany

F. Oeffner

Centre of Human Genetics, University of Marburg,

Marburg, Germany

J. M. Grange

Centre for Infectious Diseases and International Health,

Royal Free and University College Medical School, London, UK

Present Address:

B. Krone $(\square)$

Laboratory Medicine Institute Kassel, Druseltalstraße 61,

34131 Kassel-Wilhelmshöhe, Germany

e-mail: bkrone@medizinlabor.de lead to rational preventive and therapeutic strategies. It is possible that, in the future, MS could be prevented by vaccination against EBV in early childhood; the framework is of relevance to the design of an appropriate type of vaccine.

Keywords Multiple sclerosis · Common infections · Epstein-Barr virus · Hygiene hypothesis .

Endogenous retroviruses - Immunologic network

\section{Introduction}

The pathogenesis of multiple sclerosis (MS) is certainly complex and heterogeneous in nature [1], involving an interplay between innate and environmental factors [2-4] and genetic factors, notably the polymorphism of HLA [5]. The epidemiology of this disease strongly indicates that it has emerged as a major neurological disorder in industrially developed nations over the last 150 years and is likely to be affected by hygiene-related factors $[3,6]$.

According to the so-called hygiene hypothesis [7], modern living conditions in the industrialised nations isolate infants and children from many infectious challenges that are required for the development of appropriate immunoregulatory networks. This hypothesis has been advanced to explain the rise in incidence of disease associated with immune dysregulation, including asthma, allergy, autoimmunity and at least some forms of cancer, in the industrially developed world [7]. In addition, the hypothesis suggests strategies for interventions for the prevention of such diseases, as illustrated by studies on the epidemiology of malignant melanoma which indicate that certain vaccinations, BCG, vaccinia and yellow fever, can substitute for the significant protective effect of natural 
infections [8-11]. As epidemiological investigations on MS strongly indicate that this disease is likewise affected by hygiene-related factors and by a history of infections $[3,6]$, the challenge is to determine whether there is an underlying distortion of immune responses in this complex disease that could be prevented or corrected by therapeutic intervention.

\section{Associations of common infectious agents with MS}

Evidence from epidemiological studies of a role for any of the many common infections in the aetiology of MS is largely inconsistent $[3,6]$. This could be due to the prolonged silent stage of the disease, but recent studies on MS commencing in childhood might be able to shed light on this issue [6, 12-14]. Although there is no convincing evidence that any specific active infection directly causes MS, at least 14 specified infections have demonstrable associations with this disease on the basis of serological characteristics [2, 3, 6, 12-15], with Epstein-Barr virus (EBV) emerging as the most likely single candidate for a leading aetiological role [12-22]. This infection is unique in that the prevalence of specific antibody is consistently higher in children with MS as compared with healthy agematched controls [12-14], whereas at the typical age of onset of MS (late 20s to early 30s) nearly all patients and control subjects have already experienced EBV infection. The two key points to emerge from these studies in relation to EBV are that all children with MS had already been infected with EBV [12-14], and that the levels of antibody against the EBV EBNA1 antigen were very significantly higher in both adults and children with MS as compared with controls [13, 14, 16, 23-25]. In this context, infections with EBV usually occur in infancy in the developing nations where MS is rare while in the industrialised nations infection usually occurs later in life, often being delayed until adolescence or early adulthood.

At the time of diagnosis of MS in children, the earlier EBV infection had become latent and there was no serological sign of reactivation (IgM or anti-early antigen titres $\geq 80$ as measured in an indirect immuno fluorescent assay) $[12,13]$. Moreover, in adult patients, the MS-associated serological EBV pattern was probably established many years before the onset of clinically evident MS as prior infectious mononucleosis is a strong risk factor for MS manifesting 2-20 years (mean around 10-12 years) later $[18,25]$. Taken together, these studies strongly indicate that latent $\mathrm{EBV}$ infection is an essential predisposing condition for the development of MS but other genetic, environmental and hygiene-related conditions appear necessary for the actual expression of the disease and the unifying condition might be a dysregulated immune response.
A distinct possibility is that other infections synergise with EBV in the aetiology of the disease and the timing of infections might be important. In this context, Chlamydia pneumoniae (CP) infection may play a special role [26], as in a recent study on children with MS, CP-specific IgM antibody points to a high frequency of fresh, recent or reactivated infection with this pathogen at the onset of the disease [12]. A final key point is the demonstration that slight, though statistically significant, elevated levels of antibody to certain common infectious agents other than EBV and CP occur in children and adults with MS compared with age matched control subjects [12, 15, 27]. This finding does not, however, imply a direct causative relation of any infection to MS as it could reflect a more general dysregulation of immune function as a cause or consequence of the development of the disease. It is indeed likely that the elevated antibody concentrations have no significance per se for the development of MS but reflect a shift in patterns of immune reactivity away from a protection and towards enhancement of the risk of disease. Nevertheless, studies on these MS-associated infectious agents could lead to the identification of specific antigenic determinants involved in the generation and maintenance of immune dysregulation.

\section{A hypothesis which relates MS to the 'biography' of the immune system}

On the basis of the available epidemiological evidence it may be postulated that MS is dependent on an infection with EBV which, owing to hygiene-related factors, occurs later than usual in life. Under such circumstances, the EBV infection might encounter patterns of immune responsiveness generated by prior infections with certain other microorganisms. In this paper we suggest a scenario in which the sequence of certain common infections results in immune dysregulation favouring the onset of MS and in the following sections this hypothesis is elaborated.

\section{The 'biography hypothesis' and regulatory T-cells}

Recent studies have shown that the immune system contains a very complex network of regulatory pathways. To some extent these pathways are genetically determined, but there is growing evidence that they are critically determined by the nature and timing of infections and other immune challenges that an individual experiences earlier in life. This could be termed the 'biography' of the immune system.

The immunoregulatory pathways are based on populations of lymphocytes, termed regulatory $\mathrm{T}$ cells $\left(\mathrm{T}_{\mathrm{reg}} \mathrm{s}\right)$, in 
which there is currently considerable interest. In the case of infectious disease, such populations may lead to rapid resolution, the establishment of latent or persistent infection or to tissue damage by autoimmune processes [28]. Accordingly, $\mathrm{T}_{\mathrm{reg}} \mathrm{s}$ have been termed 'a dangerous necessity' [29]. This term implies that $\mathrm{T}_{\mathrm{reg}} \mathrm{s}$ are neither 'good' or 'bad' per se but may, according to the overall pattern of responsiveness, participate in appropriate immune reactions leading to resolution of disease or in inappropriate ones resulting in immunopathology.

The temporal sequence of infections, especially initial and early ones, is crucial to the development of patterns of immune reactivity as prior contacts with other antigens may have induced cross-reactive $\mathrm{T}$-helper cells competing with $\mathrm{T}_{\text {reg }} \mathrm{s}$. As a consequence $\mathrm{T}_{\text {reg }} \mathrm{s}$ normally induced by the second pathogen may be marginalized or even eclipsed. The latter phenomenon, also known as lateral inhibition, has many parallels in biology, particularly in neurology. The locking of an immune response into an eclipsed state seems to involve an active deletion of clones of T-cells occurring as a result of reinfections or reactivations [28]. In the case of MS, infections such as those with HHV-6 [30, 31] and, possibly, with CP [12, 26] occurring before or at the time of initial or reactivated EBV infection could have such an effect.

Thus these prior contacts could have induced populations of $\mathrm{T}_{\text {reg }} \mathrm{s}$ that have a crucial role in protection against MS but also cross-react with an epitope on EBV. A subsequent infection by EBV could therefore generate a dominant population of cross-reactive T-helper-cells which could suppress or delete the $\mathrm{T}_{\text {reg }} \mathrm{s}$.

Under normal physiological conditions, these $\mathrm{T}_{\text {reg }} \mathrm{s}$ could either suppress other populations of T-cells which would otherwise be able to induce autoimmune processes, including those involved in the pathogenesis of MS, or they could cause the expansion of a population of specific $\mathrm{CD} 8^{+} \mathrm{T}$-cells which would have an immune repair function. The nature of the epitope or epitopes involved in this postulated process remains unknown but, by analogy with the parallel studies on melanoma mentioned above $[10,11]$, it is suggested that key host epitopes involved are coded for by certain human endogenous retroviruses (HERVs) as activation of these has been extensively documented in MS [32, 33].

Accordingly, a challenge in MS research is to delineate patterns of MS-related immune responses [34, 35], and the $\mathrm{T}_{\text {reg }} \mathrm{s}$ involved, that affect the risk of MS both beneficially and detrimentally and the likely targets of these responses.

The IgG-anti-EBNA1 antibody concentrations are particularly elevated in patients with MS [13, 14, 16, 18, 2325 ], and systematic studies on the T-helper cell epitopes in the EBNA1 protein revealed that $\mathrm{CD}^{+}$T-cells from healthy EBV carriers matched for MS-associated HLA-DR alleles recognised several epitopes within the central region of the C-terminal domain of this protein but not other EBVencoded proteins [36, 37]. In contrast, those from MS patients recognised many more epitopes spread over the entire domain [36]. Concomitantly, the number of memory T-cells directed against this domain is increased about tenfold in MS and have been shown to be T-helper 1 cell precursors and polarised effector memory cells [36, 37], containing a subfraction of regulatory T-cells $\left(\mathrm{T}_{\text {reg }} \mathrm{s}\right)$ $[38,39] . \mathrm{T}_{\text {reg }} \mathrm{s}$ were suppressed in MS [40], and high level of $\mathrm{CD}^{+} \mathrm{T}$-cell activation against EBV but not cytomegalovirus was demonstrated early in the course of MS [41].

A search for the possible origin of competing T-helper cells was undertaken with the BLAST analytical program [42, 43]. Sequence homologies were evident over the entire expanded EBNA1 epitope with proteins from $\mathrm{CP}$ and HHV-6 (Table 1). This possible involvement of HHV-6 and $\mathrm{CP}$ in $\mathrm{T}$ cell competition is supported by the observation that the targets of $\mathrm{T}$ - and $\mathrm{B}$-cells which have been found to be MS-associated by systematic studies [34, 35] also have homologies in HHV-6 and CP (Table 2).

The central EBNA1 epitope marginalized in MS (amino acids FENIAEGLRALLARSHVER) could well have different functions in health and in MS and is therefore a major putative candidate for generation of $\mathrm{T}_{\text {reg }} \mathrm{s}$ which control the relevant immune processes. A specific or functional deficiency of $\mathrm{T}_{\mathrm{reg}} \mathrm{S}$ in MS has only recently been recognised, and the need for a large cohort of $\mathrm{T}_{\text {reg }} \mathrm{s}$ for the resolution of experimental autoimmune encephalomyelitis has been demonstrated [44]. For the purpose of studying the potential infectious and immunological background of MS, it is relevant to search for homologies to this 'epitope No. 1' in the MS-associated pathogens [42, 43]. Interestingly, homologies to the putative epitope were found in all these pathogens (Table 3).

\section{Epitopes shared by various pathogens and by a HERV peptide}

It is likely that a diverse range of MS-associated infectious agents other than EBV and, possibly, $\mathrm{CP}$, is involved in the generation and maintainance of the postulated immune responses associated, beneficially or detrimentally, with MS. By generating populations of $\mathrm{T}_{\mathrm{reg}} \mathrm{s}$ or of competing T-helper cells, such infectious agents would play a role in the generation of various immunological networks based on $\mathrm{T}_{\mathrm{reg}} \mathrm{s}$ which, in turn, would facilitate the expansion or suppression of populations of effector $\mathrm{T}$ cells including epitope-specific $\mathrm{CD}^{+} \mathrm{T}$-cells. The epitope recognised by these T-cells should be common to the MS-associated infectious pathogens and to one or more cellular gene products. The latter was preferentially sought in HERVs since patients with MS expressed HERV-W env at higher 
Table 1 Homologies in proteins of HHV-6 and Chlamydia pneumoniae (CP) to the in MS expanded T-helper cell epitope in Epstein-Barr virus EBNA1 (amino acids 400-478)

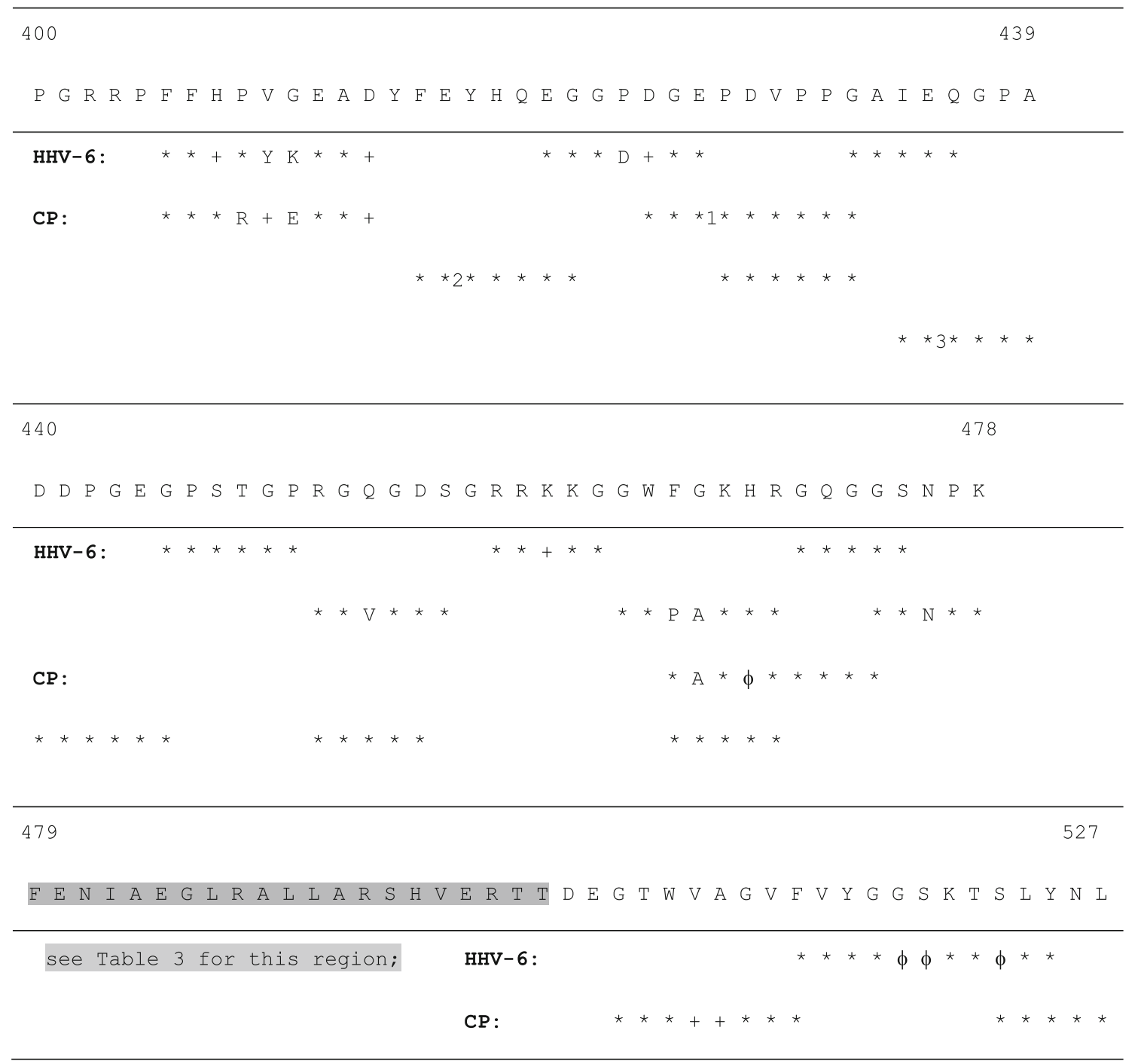

Specific T-cells directed against this region were found to be expanded in MS patients as compared to control individuals [36]; the region with homologies in HHV-6 and CP proteins extends to EBNA1 amino acid position 640

$*$ for identical amino acid; $+=$ conserved amino acid exchange; $\phi=$ missing amino acid; arabic numbers for additional amino acids: $1=\mathrm{DKK} ; 2=\mathrm{PF} ; 3=\mathrm{D}$

copy numbers as compared with controls $(P=0.00003)$ $[32,45]$ and a HERV-K18 env genotype was described as a risk factor for MS [46].

A putative target epitope for effector T-cells in the processes suggested above ('epitope No. 2') was identified in a short peptide from the HERV-W env gene complex: MPVPSAPST. It is predicted that this peptide is presented, though only subdominantly, by diverse HLA class I molecules including Ld, A*0201, B*0702, B*5101, as determined by reference to the SYFPEIHI database for MHC ligands and peptide motifs [47].

Only three pathogens bearing the two homologies on the same protein, which is postulated to be optimal for a co-operation of the corresponding T-cells, have been identified, namely, herpes simplex ( 1 and 2 ) virus (tegument protein), measles (nucleoprotein), and varicella (tegument). The MS-association of the serology of these pathogens (higher specific antibody concentration) [16] was confirmed in a recent study: herpes simplex-2, $P<0.0001$; measles, $P<0.0001$ and varicella, $P<0.0001$ [12]. The epidemiological evidence for the MS-association of the majority of the other pathogens in Table 3 is only weak and inconsistent. Moreover, a simultaneous occurrence of homologies to epitopes 1 and 2 was also found in a diverse range of pathogens causing respiratory and gastrointestinal infections and which have also been associated, beneficially and 
Table 2 Homologies in proteins of sero-epidemiologic MS-associated pathogens to MS associated EBV-epitopes [34, 35]

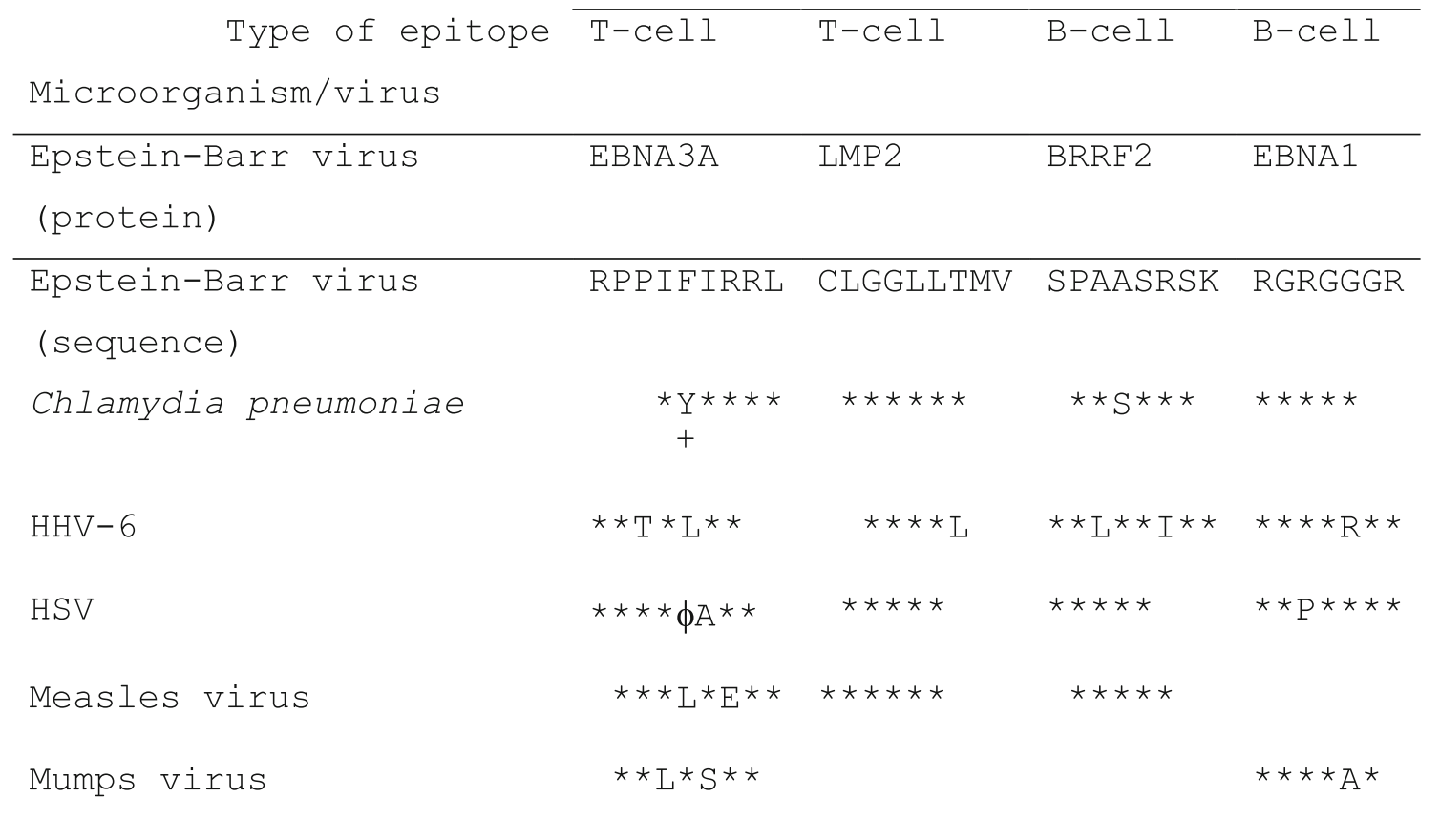

Targets of higher frequent B- and T-cells in MS-patients as present in proteins of Epstein-Barr virus and consensus in proteins of other MSassociated pathogens

Enhanced immune reactivity in MS patients in comparison with healthy control subjects as identified by systematic studies [34, 35]; consensus in other proteins to the EBV sequence given by * for identical amino acid, + for similar amino acid (conservative exchange), and $\phi$ for missing amino acid; one additional homology in vaccinia virus

detrimentally, with the risk of MS [48-50]. Likewise, unknown parasitic infections have recently been found to be associated with a reduced risk of MS [51], and some parasitic organisms share the two homologies (Table 3, footnote). In addition, preliminary studies indicate that parasite infections in MS patients lead to fewer exacerbations and this has been linked to the emergence of $\mathrm{T}_{\text {regs }} \mathrm{s}$ [52]. The relatively widespread occurrence of these two homologies explains, at least in part, why the infectious background of MS has proved so complex and difficult to define.

The MPVPSAPST-peptide is the amino-terminal part of a small hypothetical protein of 29 amino acids encoded by the complementary DNA strand of the HERV-WE1 env gene which is conserved in all homologous HERV-W sequences in the human genome. Gene transcripts of 21 of 25 open reading frames with an initiating start codon have been found in association with MS according to genetic data bank entries. Moreover, several other HERVs (-H, -K, -L) exhibit this homology. As these HERV peptides are all self-antigens, they could serve as targets, but not as inducers, of the postulated MS-protective immune response. The main HLA class I molecule A*0201 for the presentation of the peptide, with a frequency of about $30 \%$ in a European population, was shown to be associated with a significantly reduced $\mathrm{MS}$ risk $(\mathrm{OR}=0.52, P=0.0015)$ [53].

\section{A view on early events in the natural history of MS}

Immune dysregulation in MS is likely to be an early event $[18,22,25,41]$ preceding the onset of MS disease by many years or a decade [18, 22, 25]. It should thus be emphasized that the epidemiologic observations on the possible infectious background of MS partly, if not predominantly, reflect the earliest stage in the natural history of MS. A situation similar to that postulated here has been described in malignant melanoma in which, as discussed above, cross-reactive protective immune responses are induced by homologous epitopes in BCG, vaccinia and yellow fever vaccines given at least 10 years before the onset of disease [8-11]. It was suggested that melanocytes in the early stages of malignant transformation, may be eliminated or repaired by $\mathrm{CD}^{+}$T-cells which recognise cells expressing a HERV peptide. This immune reaction seems to suppress the genetic activity of HERV proviruses (env genes) associated with malignant transformation [10, 54, 55]. The HERV env proteins probably impair the redox 
Table 3 MS-associated pathogens and homologies in proteins thereof to candidate epitopes No. 1 (EBV EBNA1, putative Treg) and No. 2 (HERV-W)

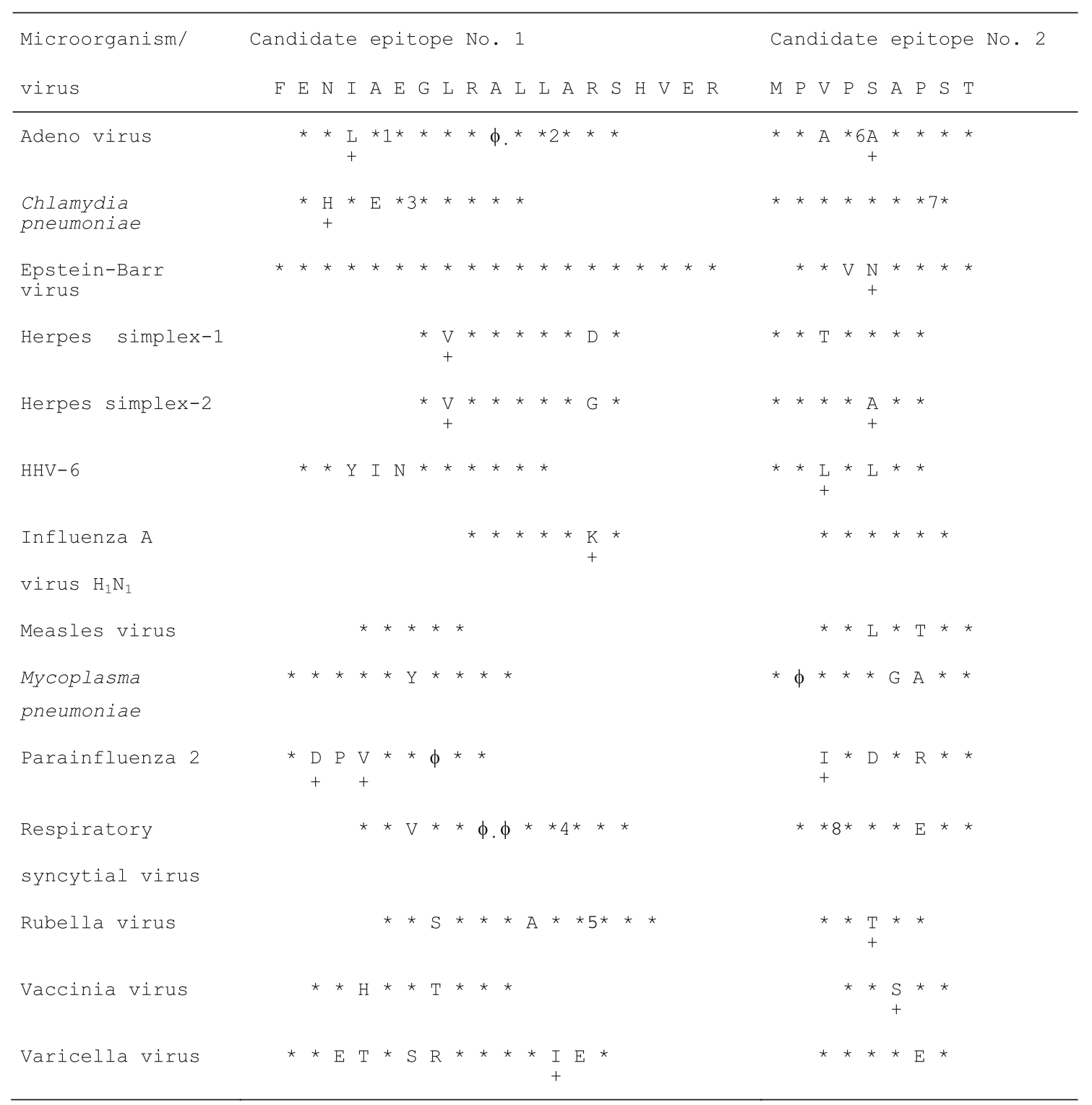

* for identical amino acid; $+=$ conserved amino acid exchange; $\phi=$ missing amino acid; arabic numbers for additional amino acids: $1=$ TEE; $2=\mathrm{AG} ; 3=\mathrm{QKE} ; 4=\mathrm{YCK} ; 5=\mathrm{AT} ; 6=\mathrm{V} ; 7=\mathrm{V} ; 8=\mathrm{LAT}$

Pathogens against which higher antibody concentrations were observed as compared with control individuals. Homologies to both epitopes were also found in the following pathogens causing respiratory and gastrointestinal diseases: Bordetella parapertussis, Corynebacterium diphtheriae, cytomegalo virus, Haemophilus influenzae, human corona virus, human rota virus, Mycobacterium tuberculosis (also M. bovis, strain BCG), Salmonella enterica, Pseudomonas aeruginosa, Serratia marcescens, A and in two parasites causing gastrointestinal infections: Entamoeba histolytica, Giardia lamblia

Proteins with homologies to epitope 1/epitope 2, respectively: adeno virus: DNA stabilization protein/protein V; Chlamydia pneumoniae: hypothetical protein cpB U609/hypothetical protein; Epstein-Barr virus: EBNA1/BBLF2/BBLF3; herpes simplex-1: tegument/tegument; herpes simplex-2: tegument/tegument; HHV-6: tegument/major capsid; measles virus: nucleoprotein/nucleoprotein; Mycoplasma pneumoniae: phosphate import ATP-binding protein pstB/enolase; parainfluenza-2: large protein/nucleocapsid; RSV: fusion protein precursor/glycoprotein; rubella: RNA-directed RNA polymerase/E1; vaccinia: $14 \mathrm{~K}$ membrane protein/putative DNA-binding core; varicella virus: tegument/tegument

regulation within the cells via reduced levels of glutathione peroxidase [10]. In MS there is still another environmental risk factor, namely, suboptimal levels of bio-active vitamin $\mathrm{D}$ [4], which, as demonstrated in rat astrocytes, may impair via $\gamma$-glutamyl transpeptidase intra-cellular glutathione levels [56]. 
In cell culture experiments, gangliosides of the neolacto series, such as LM1, were identified as possible relevant mediators as they suppress HERV genes [10] and induce lytic replication cycles in cells latently infected with EBV $[57,58]$, thereby releasing a viral antigen which would be readily recognisable by the specific immune system. The failure of such protective mechanisms would facilitate an uncontrolled establishment of the observed extensive EBV infection of brain lymphatic tissue in MS, albeit only at a low level of virus activity [59-62]. The specificity of the process for the brain may be associated with the high content of gangliosides in nervous tissue, as other gangliosides may antagonize the activity of those that possibly protect against MS.

Multiple sclerosis is certainly a complex disease entity and the pathogenic process involves more than just increased neuro-degeneration. In particular, reduced remyelination contributes to disease progression. Thus, relevant targets in addition to the HERV peptide might exist, possibly host proteins with a homology to the HERV peptide. One such candidate is neuron-specific ankyrin-2 which, owing to complementary binding sites, forms a complex with spectrin. In an animal model of remyelination of axons the latter is the target of an immune repair mechanism mediated by a monoclonal antibody [63].

\section{Conclusion}

Based on epidemiological considerations, it is postulated that the relatively high risk of MS in the industrialised nations is due to hygiene-related changes in the sequence of common infections, resulting in the emergence of patterns of immune reactivity that either cause, or fail to protect against, the development of MS. Further epidemiological studies are required to determine whether the timing of EBV infection is related to the risk of MS [20]. Based on studies of altered immune responses to certain infectious agents and evidence for the expression of HERVs in MS, epitopes that have a putative role, depending on the appropriate or inappropriate activity of immunoregulatory networks, in protection against or predisposition to MS have been delineated.

Studies based on the above considerations should focus on processes that initiate MS years or a decade before manifestation of the disease. Subsequently, a better understanding of the highly complex immunopathology of MS will, hopefully, lead to the eventual development of vaccination strategies for the prevention or correction of anomalies in immune function. Such vaccines could well work by preventing or correcting hygiene-related immune dysregulation [64]. It has previously been postulated that a vaccine based on EBV should afford a high level of protection against MS [16], but the exact nature of an efficient and safe vaccine would depend on the nature of the relationship between EBV and MS. If the framework presented in this study is in principle confirmed, the appropriate vaccine is most likely to be a living attenuated one that induces a strong $\mathrm{T}$ cell response to EBV epitopes but is not expressing EBV EBNA1 in latency.

Acknowledgments We thank F. Hanefeld, G. Hunsmann, J. H. Peters, H. Reiber, and H. Reichardt, Göttingen, Germany, for valuable discussion.

Conflict of interest statement The authors declare no conflicts of interest.

Open Access This article is distributed under the terms of the Creative Commons Attribution Noncommercial License which permits any noncommercial use, distribution, and reproduction in any medium, provided the original author(s) and source are credited.

\section{References}

1. Lassmann H, Brück W, Lucchinetti CF (2007) The immunopathology of multiple sclerosis: an overview. Brain Pathol 17:210 218. doi:10.1111/j.1750-3639.2007.00064.x

2. Giovanni G, Ebers G (2007) Multiple sclerosis: the environment and causation. Curr Opin Neurol 20:261-268

3. Ascherio A, Munger KL (2007) Environmental risk factors for multiple sclerosis. Part I: the role of infection. Ann Neurol 61:288-299. doi:10.1002/ana.21117

4. Ascherio A, Munger KL (2007) Environmental risk factors for multiple sclerosis. Part II: non-infectious factors. Ann Neurol 61:504-513. doi:10.1002/ana.21141

5. The International Multiple sclerosis Genetics Consortium (2007) Risk alleles for multiple sclerosis identified by a genome wide study. N Engl J Med 357:851-862. doi:10.1056/NEJMoa073493

6. Fleming J, Fabry Z (2007) The hygiene hypothesis and multiple sclerosis. Ann Neurol 61:85-88. doi:10.1002/ana.21092

7. Stanford JL, Stanford CA, Grange JM (2001) Environmental echoes. Sci Prog 84(Part 2):105-124. doi:10.3184/00368 5001783239014

8. Pfahlberg A, Kölmel KF, Grange JM, Mastrangelo G, Krone B, Botev IN et al (2002) Inverse association between melanoma and previous vaccinations against tuberculosis and smallpox: results of the FEBIM study. J Invest Dermatol 119:570-575. doi:10.1046/j.1523-1747.2002.00643.x

9. Kölmel KF, Grange JM, Krone B, Mastrangelo G, Rossi CR, Henz BM et al (2005) Prior immunization of patients with malignant melanoma with vaccinia or BCG is associated with a better survival. An European Organization for Research and Treatment of Cancer cohort study on 542 patients. Eur J Cancer 41:118-125. doi:10.1016/j.ejca.2004.09.023

10. Krone B, Kölmel KF, Henz BM, Grange JM (2005) Protection against melanoma by vaccination with Bacille Calmette-Guérin (BCG) and/or vaccinia: an epidemiology-based hypothesis on the nature of a melanoma risk factor and its immunological control. Eur J Cancer 41:104-117. doi:10.1016/j.ejca.2004.08.010

11. Mastrangelo G, Krone B, Fadda E, Grange JM, Buja A, de Vries $E$ et al (2009) Does yellow fever 17D vaccine protect against melanoma? Vaccine 27:588-591. doi:10.1016/j.vaccine.2008. 10.076 
12. Krone B, Pohl D, Rostasy K, Kahler E, Brunner E, Oeffner F et al (2008) Common infectious agents in multiple sclerosis: a case control study in children. Mult Scler 14:136-139. doi:10.1177/ 1352458507082069

13. Pohl D, Krone B, Rostasy K, Kahler E, Brunner E, Lehnert M et al (2006) High seroprevalence of Epstein-Barr virus in children with multiple sclerosis. Neurology 67:2063-2065. doi:10.1212/01.wnl. 0000247665.94088.8d

14. Banwell B, Krupp L, Kennedy J, Tellier R, Tenebaum S, Ness J et al (2007) Clinical features and viral serologies in children with multiple sclerosis: a multinational observational study. Lancet Neurol 6:773-781. doi:10.1016/S1474-4422(07)70196-5

15. Haahr S, Höllsberg P (2001) The ability of candidate viruses to explain the epidemiological findings in multiple sclerosis. In: Hommes OR, Clanet M, Wekerle $\mathrm{H}$ (eds) Genes and viruses in multiple sclerosis. Elsevier Science, Amsterdam, pp 163-184

16. Haahr S, Höllsberg P (2006) Multiple sclerosis is linked to Epstein-Barr virus infection. Rev Med Virol 16:297-310. doi:10.1002/rmv.503

17. Giovannoni G, Cutter GR, Lünemann J, Martin R, Münz C, Sriam S et al (2006) Infectious causes of multiple sclerosis. Lancet Neurol 5:887-894. doi:10.1016/S1474-4422(06)70577-4

18. DeLorenze GN, Munger KL, Lennette ET, Orentreich N, Vogelman JH, Ascherio A (2006) Epstein-Barr virus and multiple sclerosis: evidence of association from a prospective study with long-term follow-up. Arch Neurol 63:839-844. doi:10.1001/ archneur.63.6.noc50328

19. Ascherio A, Munger KL, Lennette ET, Spiegelman D, Hernán MA, Olek MJ et al (2001) Epstein-Barr virus antibodies and risk of multiple sclerosis: a prospective study. JAMA 286:3083-3088. doi:10.1001/jama.286.24.3083

20. Haahr S, Plesner AM, Vestergaard BF, Höllsberg P (2004) A role of late Epstein-Barr virus infection in multiple sclerosis. Acta Neurol Scand 109:270-275. doi:10.1046/j.1600-0404.2003. 00221.x

21. Levin LI, Munger KL, Rubertone MV, Peck CA, Lennette ET, Spiegelman D et al (2003) Multiple sclerosis and Epstein-Barr virus. JAMA 289:1533-1536. doi:10.1001/jama.289.12.1533

22. Thacker EL, Mirzaei F, Ascherio A (2006) Infectious mononucleosis and risk for multiple sclerosis: a meta-analysis. Ann Neurol 59:499-503. doi:10.1002/ana.20820

23. Lünemann JD, Huppke P, Roberts S, Brück W, Gärtner J, Münz C (2008) Broadened and elevated humoral immune response to EBNA1 in pediatric multiple sclerosis. Neurology 71:1033-1035. doi:10.1212/01.wnl.0000326576.91097.87

24. Pender MP, Csurhes PA, Lenarczyk A, Pfluger CM, Burrows SR (2008) Decreased T-cell reactivity to Epstein-Barr virus-infected lymphoblastoid cell lines in multiple sclerosis. J Neurosurg Psychiatry (Epub ahead of print). doi:10.1136/jnnp.2008.161018

25. Levin LI, Munger KL, Rubertone MV, Peck CA, Lennette ET, Spiegelman D et al (2005) Temporal relationship between elevation of Epstein-Barr virus antibody titers and initial onset of neurological symptoms in multiple sclerosis. JAMA 293:24692500. doi:10.1001/jama.293.20.2496

26. Bagos PG, Nikolopoulos G, Ioannidis A (2006) Chlamydia pneumoniae infection and the risk of multiple sclerosis: a meta analysis. Mult Scler 12:397-411. doi:10.1191/1352458506ms1291 oa

27. Cook SD, Rohowsky-Kochan C, Bansil S, Dowling PC (1995) Evidence for multiple sclerosis as an infectious disease. Acta Neurol Scand Suppl 161:34-42

28. Kim S-K, Welsh RM (2004) Comprehensive early and lasting loss of memory CD8 T cells and functional memory during acute and persistent viral infections. J Immunol 172:3139-3150

29. Belkaid Y (2007) Regulatory T cells and infection: a dangerous necessity. Nat Rev Immunol 7:875-888. doi:10.1038/nri2189
30. Höllsberg P, Kusk M, Bech E, Hansen HJ, Jacobsen J, Haahr S (2005) Presence of Epstein-Barr virus and human herpes virus 6B in multiple sclerosis: association with clinical activity. Acta Neurol Scand 112:395-402. doi:10.1111/j.1600-0404.2005. 00516.x

31. Alvarez-Lafuente R, Garcia-Montojo M, De Las Heras V, Dominguez-Mozo MI, Bartolome M, Benito-Martin MS et al (2008) Herpesviruses and human endogenous retroviral sequences in the cerebrospinal fluid of multiple sclerosis patients. Mult Scler 14:595-601. doi:10.1177/1352458507086425

32. Perron H, Lazarini F, Ruprecht K, Péchoux-Longin C, Seilhean D, Sazdovich V et al (2005) Human endogenous retroviruses (HERV)-W ENV and GAG proteins: physiological expression in human brain and pathophysiological modulation in multiple sclerosis. J Neurovirol 11:22-33

33. Mameli G, Astone V, Arru G, Marconi S, Lovato L, Serra C et al (2007) Brains and peripheral blood mononuclear cells of multiple sclerosis patients hyperexpress MS-associated retroviruses, but not human herpesvirus 6. J Gen Virol 88:264-274. doi:10.1099/ vir.0.81890-0

34. Höllsberg P, Hansen HJ, Haahr S (2003) Altered $\mathrm{CD}^{+}{ }^{+}$cell responses to selected Epstein-Barr virus immunodominant epitopes in patients with multiple sclerosis. Clin Exp Immunol 132:137-143. doi:10.1046/j.1365-2249.2003.02114.x

35. Cepok S, Zhou D, Srivastava R, Nessler Stei S, Büssow K et al (2005) Identification of Epstein-Barr virus proteins as putative targets of the immune response in multiple sclerosis. J Clin Invest 115:1352-1360

36. Lünemann JD, Edwards N, Muraro PA, Hayashi S, Cohen JI, Münz $C$ et al (2006) Increased frequency and broadened specificity of latent EBV nuclear antigen-I-specific T cells in multiple sclerosis. Brain 129:1493-1506. doi:10.1093/brain/aw1067

37. Lünemann JD, Jelcic I, Roberts S, Lutterotti A, Tackenberg B, Martin R et al (2008) EBNA1-specific T-cells from patients with multiple sclerosis cross react with myelin antigens and co-produce IFN-gamma and IL-2. J Exp Med 205:1763-1772. doi: 10.1084/jem.20072397

38. Gronen F, Ruprecht K, Weissbrich B, Klinker E, Kroner A, Hofstetter $\mathrm{HH}$ et al (2006) Frequency analysis of HLA-B27restricted Epstein-Barr virus-specific cytotoxic T lymphocytes in patients with multiple sclerosis and healthy controls. J Neuroimmunol 180:185-192. doi:10.1016/j.jneuroim.2006.08.008

39. Voo KS, Fu T, Heslop HE, Brenner MK, Rooney CM, Wang RF (2002) Identification of HLA-DP3-restricted peptides from EBNA1 recognized by CD4(+) T cells. Cancer Res 62:71957199

40. Viglietta V, Baecher-Allan C, Weiner HL, Hafler DA (2004) Loss of functional suppression by $\mathrm{CD} 4{ }^{+} \mathrm{CD} 25^{+}$regulatory $\mathrm{T}$ cells in patients with multiple sclerosis. J Exp Med 199:971-979. doi:10.1084/jem.20031579

41. Jilek S, Schluep M, Meylan P, Vingerhoets F, Guignard L, Monney A, Kleeberg J et al (2008) Strong EBV-specific CD8 ${ }^{+}$ T-cell-response in patients with early multiple sclerosis. Brain 131:1712-1721. doi:10.1093/brain/awn108

42. Altschul SF, Gish W, Miller W, Lipman DJ (1990) Basic local alignment search tool. J Mol Biol 215:403-410

43. Kuttler C, Nussbaum AK, Dick TP, Rammensee HG, Schild H, Hadeler KP (2000) An algorithm for the prediction of proteasomal cleavages. J Mol Biol 298:417-429. Erratum in J Mol Biol 2000; 301:229. doi:10.1006/jmbi.2000.3683

44. Haas J, Fritzsching B, Trübswetter P, Korporal M, Milkova L, Fritz B et al (2007) Prevalence of newly generated naïve regulatory $\mathrm{T}$ cells $\left(\mathrm{T}_{\mathrm{reg}}\right)$ is critical for $\mathrm{T}_{\text {reg }}$ suppressive function and determines $\mathrm{T}_{\text {reg }}$ dysfunction in multiple sclerosis. J Immunol 179:1322-1330 
45. Dolei A, Perron H (2008) The multiple sclerosis-associated retrovirus and its HERV-W endogenous family: a biological interface between virology, genetics and immunology in human physiology and disease. J Neurovirol Nov 27:1-10 (Epub ahead of print)

46. Tai A, O'Reilly E, Alroy K, Simon K, Munger K, Huber B et al (2008) Human endogenous retrovirus-K 18 Env as a risk factor in multiple sclerosis. Mult Scler 14:1175-1180. doi:10.1177/ 1352458508094641

47. Rammensee HG, Bachmann J, Emmerich NN, Bachor OA, Stevanovic S (1999) SYFPEITHI: database for MHC ligands and peptide motifs. Immunogenetics 50:213-219. http://www. syfpeithi.de. doi:10.1007/s002510050595

48. Sibley WA (2001) The effect of virus-like infections on the course of multiple sclerosis. In: Hommes OR, Clanet M, Wekerle $\mathrm{H}$ (eds) Genes and viruses in multiple sclerosis. Elsevier Science B. V, Amsterdam, pp 92-98

49. Ponsonby AL, van der Mei I, Dwyer T, Blizzard L, Taylor B, Kemp A (2005) Exposure to infant siblings during early life and risk of multiple sclerosis. JAMA 293:439-463. doi:10.1001/jama. 293.4.463

50. Sadovnick AD, Lee IML, Ebers GC, the Canadian Collaborative Study Group (2005) Multiple sclerosis and birth order: a longitudinal cohort study. Lancet Neurol 4:611-617. doi:10.1016/ S1474-4422(05)70170-8

51. Correale J, Farez M (2007) Association between parasite infection and immune responses in multiple sclerosis. Ann Neurol 61:97-108. doi:10.1002/ana.21067

52. O'Connor RA, Malpass KH, Anderton SM (2007) The inflamed central nervous system drives the activation and rapid proliferation of Foxp3 ${ }^{+}$regulatory T cells. J Immunol 179:958-966

53. Chao MJ, Barnardo MC, Lincoln MR, Ramagopalan SV, Herrera BM, Dyment DA et al (2008) HLA class I alleles tag HLADRB $1 * 1501$ haplotypes for differential risk in multiple sclerosis susceptibility. Proc Natl Acad Sci USA 105:13069-13074. doi:10.1073/pnas.0801042105

54. Ritter K, Härtl R, Bandlow G,Thommsen R (1986) Cytostatic effect of gangliosides present in the membrane of macrophages. Cell Immunol 97:248-256. doi:10.1016/0008-8749(86)90395-3
55. Nojiri H, Kitagawa S, Nakamura M, Kirito K, Enomoto Y, Saito M (1988) Neolacto-series gangliosides induce granulocytic differentiation of human promyelotic leukaemia cell line HL-60. J Biol Chem 263:7443-7446

56. Garcion E, Sindji L, Leblondel G, Brachet P, Darcy F (1999) 1 , 25-Dihydroxyvitamin D3 regulates the synthesis of gammaglutamyl transpeptidase amd glutathione levels in primary rat astrocytes. J Neurochem 73:859-866. doi:10.1046/j.1471-4159. 1999.0730859.x

57. Schaade L, Kleines M, Walter R, Thomssen R (1999). A membrane-located glycoshingolipid of monocyte/granulocyte lineage cells induces growth arrest and triggers the lytic cycle in EpsteinBarr virus genome positive Burkitt-lymphoma lines. Microbiol Immunol 188:23-29. doi:10.1007/s004300050101

58. Schaade L, Kleines M, Krone B, Hausding M, Walter R, Ritter K (2000) Enhanced transcription of the S-adenosylhomocystein hydrolase gene precedes Epstein-Barr virus lytic gene activation in ganglioside stimulated lymphoma cells. Microbiol Immunol 189:13-18. doi:10.1007/PL00008252

59. Serafini B, Rosicarelli B, Franciotta D, Magliozzi R, Reynolds R, Cinque $P$ (2007) Dysregulated Epstein-Barr virus infection in the multiple sclerosis brain. J Exp Med 204:2899-2912. doi:10.1084/ jem.20071030

60. Franciotta D, Salvetti M, Lolli F, Serafini B, Aloisi F (2008) B cells and multiple sclerosis. Lancet Neurol 7:852-858. doi:10.1016/ S1474-4422(08)70192-3

61. Torkildson O, Nyland H, Myrmel H, Myhr KM (2008) EpsteinBarr virus reactivation and multiple sclerosis. Eur $\mathrm{J}$ Neurol 15:106-108

62. Lindsey J, Hatfield L, Crawford M, Patel S (2009) Quantitative PCR for Epstein-Barr virus DNA and RNA in multiple sclerosis. Mult Scler 15:153-158

63. Miller DJ, Rodriguez M (1995) A monoclonal autoantibody that promotes central nervous system remyelination in a model of multiple sclerosis is a natural autoantibody encoded by germline immunoglobulin genes. J Immunol 154:2460-2469

64. Rook GA, Stanford JL (1998) Give us this day our daily germs. Immunol Today 19:113-116. doi:10.1016/S0167-5699(97) 01204-8 